Article

\title{
Property Rights and the Soybean Revolution: Shaping How China and Brazil Are Telecoupled
}

\author{
Sara M. Torres ${ }^{1, *}$, Emilio F. Moran ${ }^{1}$ and Ramon Felipe Bicudo da Silva ${ }^{2}$ \\ 1 Department of Geography, Environment, and Spatial Sciences at Michigan State University, East Lansing, \\ MI 48823, USA; moranef@msu.edu \\ 2 Center for Environmental Studies and Research, State University of Campinas, 13083-867 Campinas, Brazil; \\ ramonbicudo@gmail.com \\ * Correspondence: torress9@msu.edu; Tel.: +1-720-988-9749
}

Academic Editor: Harini Nagendra

Received: 4 April 2017; Accepted: 1 June 2017; Published: 5 June 2017

\begin{abstract}
China currently has the largest population in the world and is currently experiencing rapid economic and urban growth, becoming the world's number one pork and poultry consumer. In order to meet this growing demand for meat, China has increased its demand for soybeans to produce chicken and pork. It has imported soybeans from the United States, Brazil, and Argentina, while keeping its soybean production for direct human consumption stable at home. Brazil has become the largest soybean exporter to China, and, in response specifically to Chinese demand, has become the second largest producer of soybeans in the world. This has changed land use in Brazil, particularly in its central plateau. In this paper, we indicate how these two countries, telecoupled by trade in soybeans, are depending on each other as they try to balance environmental and economic objectives. Brazil, as a sending system, has created pressures on its natural ecosystems, which have led to losses particularly in the Cerrado biome and its ecotones in the Amazon's tropical moist forest biome. China, as a receiving system, has created a land asset important to regenerating its lost natural systems (e.g., forest cover areas). Both countries have different property rights regimes, which have created distinct circumstances in which they are to protect or regenerate their natural ecosystems. Throughout this paper, we analyze how both countries have dealt with the lure offered by the soybean commodity trade.
\end{abstract}

Keywords: property rights; telecoupling; agribusiness; Brazil; China

\section{Introduction}

China has a population of over 1.3 billion people and is today the second largest economy in the world, according to the World Bank [1]. The GDP growth of China has averaged nearly $10 \%$ per year over the last 30 years, and, in what is reported as a slowdown in its economy, is growing at $6.7 \%$ for 2015 [1]. This rapid economic growth has had effects on Chinese society, resulting in, among other things, an increase in animal protein consumption, which accompanies improved incomes [2,3]. The other big change - and one profoundly related to it - is the rapid urbanization of China, which has gone from $42.52 \%$ urban to $55.61 \%$ urban between 2005 and 2015 [4]. The change from rural to urban has also contributed to the dietary shift towards more animal protein consumption. According to Larsen [2], China has become the world's number one pork and poultry consumer, surpassing the US in 1992 (Figure 1). 


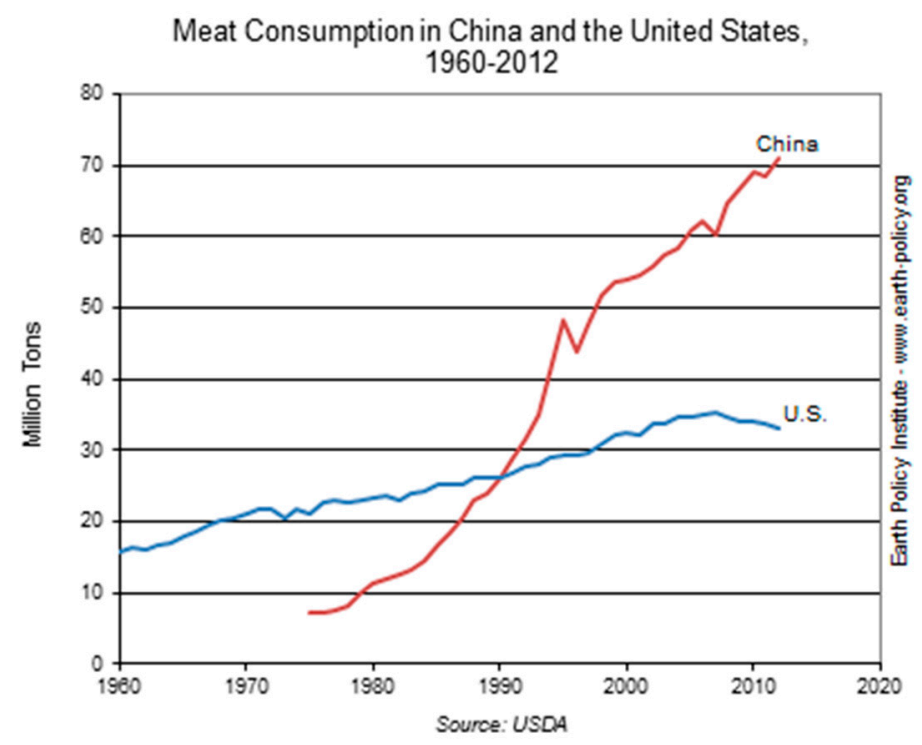

Figure 1. Absolute meat consumption in China and the US, from Larsen [2].

This transformation has resulted in a conversion from the local, small-scale production of pork and poultry for a mostly rural population, to more specialized livestock operations that use mostly soybean-based feed, and that feed the growing urban populations. More than $60 \%$ of the world's exports of soybean go to China from the United States, Brazil, and Argentina [2]. Of these three countries, Brazil is the greatest contributor with $46.3 \%$ currently, having surpassed the US-who provided $39.2 \%$ of the Chinese soybean imports in 2016 [5]—as a soybean exporter to China [6]. The amount of Brazilian soybean exported to China in 2016 represented $40 \%$ of the country's production [6]. These imports provide the feed necessary to expand pork and poultry production in China. This trade relationship across the world has coupled human and natural systems, and has implications within and between Brazil and China. In the literature, this global coupling of human and natural systems has come to be known as the integrated framework of telecoupling (socioeconomic and environmental interactions over distances) [7]. In this approach, each country is considered a coupled human and natural system, and two or more coupled natural and human systems affect each other across long distances with unintended consequences on the sending and receiving trade partners. This telecoupling approach contrasts with traditional coupled human-natural systems that focus on one system, or with economic trade approaches that overlook dimensions such as property rights, environmental outcomes such as deforestation, and the role of institutions.

A lesser known fact is that in this process of soybean imports (most recently up to 70 million tons), the annual production of soybeans within China has not declined, but has remained stable since the mid-1980s. In 1984, China consumed the 14 million tons of soybean it produced, and in 2014 it was still producing 14 million tons (Figure 2). What had changed was the increase in its consumption from those 14 million tons to 70 million tons, a change met by increasing importations of soybeans [2], and greater productivity per hectare from areas in soybeans in China, resulting from major investments in agricultural research (going from 1.3 tons per hectare to 1.8 tons per hectare between 1984 and 2014). Nonetheless, Brazil's productivity has had even greater increases during the same time frame (going from 1.6 tons per hectare to 2.9 tons per hectare between 1984 and 2014). The increased production of soybeans in Brazil (Figure 2), incentivized to meet this demand, has resulted in the expansion of the planted soybean area from 1.2 to 2.5 million hectares in ten years (2003 to 2013) in the MATOPIBA (an area encompassing MAranhao, TOcantins, PIaui, and BAia states) agricultural frontier region alone, and over land previously covered mostly by the Cerrado biome-a tree bush savanna found in Central Brazil—rather than over pastures [8]. The total area in soybeans in Brazil is much larger than that in MATOPIBA. For instance, in Mato Grosso alone, the soybean area increased from 4.4 to 
8.9 million hectares between 2003 and 2015, which contrasts with the 32.2 million hectares planted in soybeans in Brazil during 2015 [9].

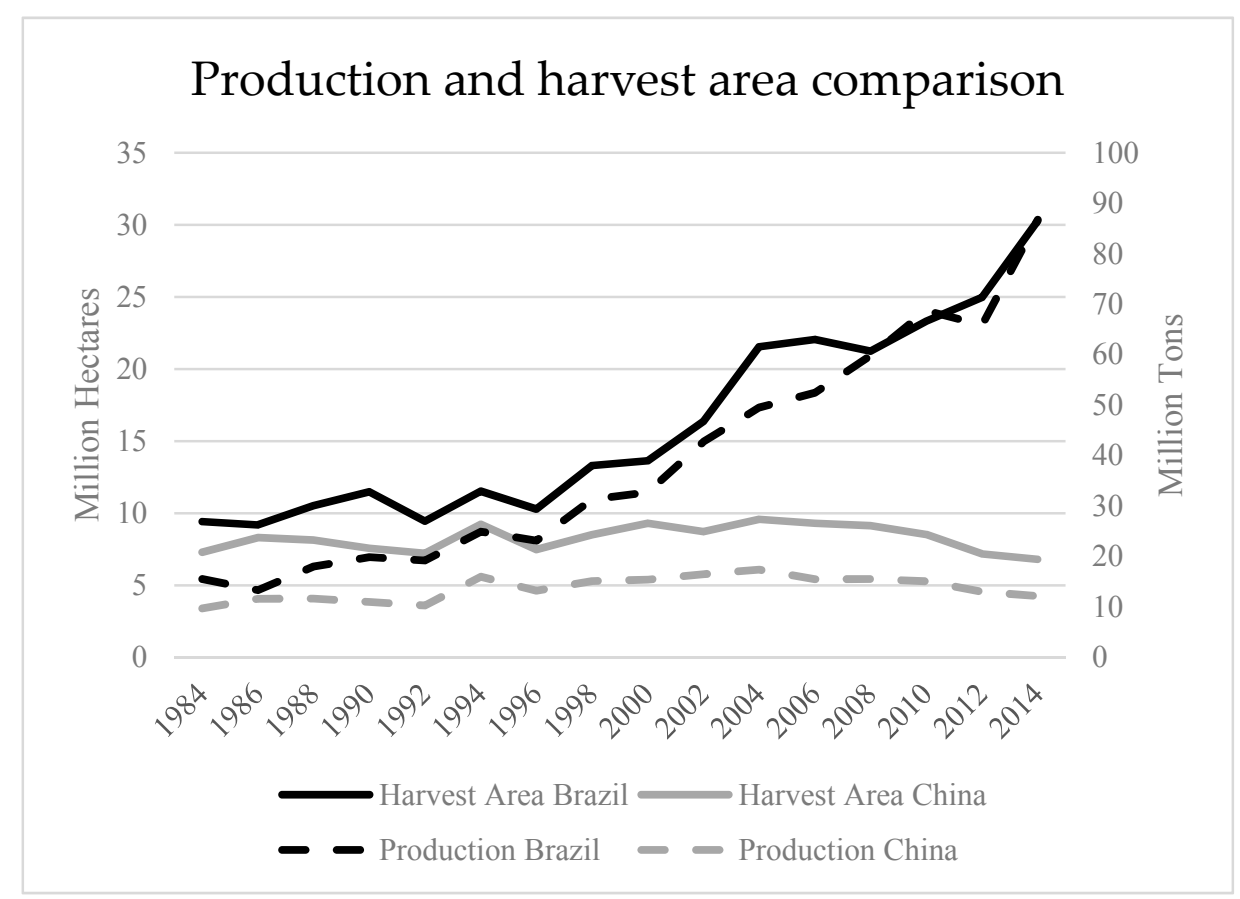

Figure 2. Soybean production in China and Brazil (Data source: FAOStat). The darker lines represent Brazil.

This situation poses different challenges to both countries. On the one hand, the sending system in the soybean trade-in this case Brazil-is ranked as one of the most biodiverse countries in the world. It holds one of the biggest carbon stocks on the planet (in the biomass of the Legal Amazon which includes Mato Grosso, the biggest producer of soybeans in Brazil). This global environmental role presents a challenge as to how to protect its natural systems under the pressure of China's demand for commodities. On the other hand, the receiving system-China-is able to maintain its soybean cultivated area by importing most of the increased demand for soybeans, without having to triple the land area for the production of the 56 million tons of additional demand. While it is impossible to know what lands China would have put into production to meet this large demand for soybeans, we can imagine that it would have had significant environmental impacts. Instead, by importing soybeans, China has been able to expand its forest cover by removing land from agricultural production (e.g., the Grain-to-Green program is but one of several policies that have led to China being a global leader in reforestation [10]). It needs to be pointed out that most of the Grain-to-Green land conversions did not involve traditional soybean producing areas: those remained, as noted earlier, in stable production. This has two consequences. First, it provides opportunities to protect and regenerate previously degraded natural systems, rather than to have to expand planted areas in soybeans into new areas or areas that might be prone to erosion (the main motivation for the reforestation programs). Second, it allows China to become a leader in carbon sequestration.

These different strategies are related to the ways each country has chosen to bundle its citizens' property rights, and the legal mechanisms available to achieve production and conservation. This bundling of rights influences whether the use of the land in each country will be sustainable. It places each country in an advantageous or disadvantageous position with respect to continuing the production of food for export, or achieving its internal consumption objectives. This paper makes the case for property rights as a platform to shape the way countries respond to the effects of their many telecoupling processes. Both Brazil and China's processes of environmental restoration or conservation 
are the result of various telecouplings, as well as other internal processes such as policies, legislation, and international treaties. We use this telecoupled relation as an example of how property rights shape the manner in which countries deal with these relations.

In the following two sections, we will examine property rights and describe the property rights regimes of both Brazil and China. Then, we will discuss the main policies that have been developed to protect and recover the natural ecosystems in each country, and how these relate to the property rights framework. Finally, we conclude with an overview of how both countries have dealt with the lure that trading in soybeans offers, and the way property rights have shaped their responses.

\section{Property Rights}

Property rights are defined as "a claim to a benefit stream that the state will agree to protect through the assignment of duty to others who may covet, or somehow interfere with, the benefit stream" [11]. This traditional view of property rights has been redesigned to allow for the dissection of these rights into various groups of rights. One typology has identified five different control rights: access, withdrawal, management, exclusion, and alienation [12]. These rights are defined by Schlager and Ostorm [12] as follows:

Access: $\quad$ The right to enter a defined physical property.

Withdrawal: The right to obtain the "products" of a resource (e.g., catch fish, appropriate water, etc.).

Management: The right to regulate internal use patterns and transform the resource by making improvements.

Exclusion: The right to determine who will have an access right, and how that right may be transferred.

Alienation: the right to sell or lease either or both of the above collective choice rights [12].

These five property rights are independent, yet usually held in a cumulative manner. As the rights are stacked on top of each other, they create different types of property rights holders, as described by Schlager and Ostrom [12] in Table 1.

Table 1. Bundles of rights associated with Positions.

\begin{tabular}{ccccc}
\hline & Owner & Proprietor & Claimant & Authorized User \\
\hline Access and withdrawal & $\mathrm{X}$ & $\mathrm{X}$ & $\mathrm{X}$ & $\mathrm{X}$ \\
Management & $\mathrm{X}$ & $\mathrm{X}$ & $\mathrm{X}$ & \\
Exclusion & $\mathrm{X}$ & $\mathrm{X}$ & & \\
Alienation & $\mathrm{X}$ & & & \\
\hline
\end{tabular}

Note: From Schlager and Ostrom, ([11], p. 252).

Table 1 illustrates how different bundles of rights may allow individuals to access and transform natural resources with different combinations of them. These combinations differ from country to country. Understanding China and Brazil's respective property rights regimes is crucial to understanding how they have approached the effects of their telecoupled relationship on protecting or regenerating natural resources. Different bundles of property rights affect the incentives that individuals in each country have to protect their land for future use.

\subsection{Rural Property in China}

In China, there are two types of land ownership: state ownership and collective ownership. According to Kram et al. [13], three major waves of land reforms have taken place:

(1) Private ownership (1930s/1940s to early/mid 1950s): The State granted individuals full ownership of agricultural land and forest land within this time period, also known as Mao's First 
Land Reform. Private property rights were not instated for grasslands, which were still managed as a common property resource.

(2) Collectivization/No individual rights (early/mid 1950s to late 1970s): The State rescinded ownership rights of individuals for agricultural lands, forests, and grasslands through collectivization.

(3) Decollectivization/Private and increasing use rights (late 1970s to present): The State granted individuals limited and short-term use rights, but not ownership, during a period of initial decollectivization in the late 1970s to mid-1980s. Since that time, the State generally has been increasing use rights granted to individuals with the exception of forests during the 1980s and 1990s. During that period, the State exerted significant control over timber harvest and other forest activities in response to the mass deforestation that occurred after use rights to forests were first distributed to households in the early 1980s [13].

Currently, the Chinese government has increased its efforts to give more security to use rights in a way that may lead to decisions that favor the long-term productivity of the land. One of the tools implemented for this was the Household Responsibility System (HRS). The HRS transferred the use and withdrawal rights from the state to households-while keeping the alienation and exclusion rights-to collectively improve the incentives for farmers to produce higher yields by implementing household output quotas [13,14]. The HRS was characterized according to Li [15] as making available access to arable land for all rural households, and providing the egalitarian distribution of land. Nonetheless, $\mathrm{Li}$ [14] also argues that in the land system, the rules and practices were not uniform throughout the country. In addition, the great majority of Chinese farm households did not possess written contracts, and most contracts lasted between 3 and 15 years even though the rule suggested that 30-year tenure contracts would be the norm.

The HRS allowed local village officials to balance two objectives. The first was to ensure the establishment and implementation of land system practices while continuing equal per capita access to land for welfare or subsistence purposes. The second was to provide stable land use rights to encourage stable productivity. To balance both objectives, a need to redistribute land often to keep up with population growth was required. This, in turn, created an environment of poor tenure security for households, which led in 2002 to the Rural Land Contracting Law (RLCL).

The RLCL, which came into force in 2003, delimits three basic rules for readjustment. It requires that all land readjustments be supported by the consent of two-thirds of the village assembly, or of the village representatives, as well as the approval of the township government and the county agricultural administrative body [15]. The measure is supposed to control the condition that allows for readjustments to occur before the 30-year term is completed. It allows for readjustments only in the case of a natural disaster that seriously damages the contracted land, or other special circumstances. This is in contrast to the original contracts which lasted between 3 and 15 years.

The RLCL also describes minimum core requirements for the rights held by farmers. These include: the right to use, profit from, and transfer land; contracting and operational rights; a right of autonomy over the production, operation, and the disposition of products; and the right to receive the corresponding compensation for any land taken by the state or collective for non-agricultural purposes. However, there is no clear understanding of the rights of farmers to inherit land, since the land contract is given to the household and not an individual. Given the variability of rights throughout China, the RLCL's strength lies also in the establishment of the minimum core requirements for contracts. These, as explained above, give land holders land security through contracts, tenure security through the requirement of a 30-year land tenure commitment, and they make it harder for readjustments to occur sooner [15].

The RLCL also requires that written contracts issued to farm households be accompanied by county-level certificates affirming their land rights. These certificates are made to protect farmers' rights in the case of a dispute, as well as to discourage possible violations of their land rights. By requiring written contracts and county-level certificates of land rights, the RLCL addresses the top concerns 
of rural land tenure: a short or uncertain length of use; a lack of written contracts; and frequent land readjustments [14]. The RLCL has increased the land tenure security as well as enhanced an individual's ability for recourse against violations of their land rights [16]. In contrast to the earlier contracts whose terms-although recommended to last 30 years-would fluctuate between 3 and 15 years in practice, the RLCL's extension of land tenure to 30 years allows individuals to make long-term decisions. The stability the RLCL creates, and the property rights it embodies, means that China can expect land use-including the cultivation of soybeans-to remain stable, which it has in fact done. On the other hand, if China had had to meet the demand for a tripling in the total amount of soybeans it needed, the RLCL would have been put to a stress test at a time when people were leaving in large numbers from rural to urban-industrial jobs, and where the amount of high quality land for soybean production may have been limited. This may have resulted in significant social and environmental impacts.

\subsection{Rural Property in Brazil}

Brazil currently has a private property rights regime. This regime's origins date back to 1850 with the Lei de Terras (Land Law) [17]. Under the current constitution in Brazil, ratified in 1988, there is a continuing emphasis on the social function of land that must be held as private property. It requires a rural property to meet three requirements: "(1) that the land in question be exploited economically in a "rational and adequate" manner; (2) that activities realized on the land comply with the labor code; and (3) that the natural resources on the property be exploited in a way that preserves the natural environment" [18]. The non-fulfillment of the social function gives the federal government authority to expropriate those lands. While it simultaneously prohibits the expropriation of "productive" properties, this prohibition may potentially nullify the labor and environmental aspects of the social function [18]. This rule allows for landholders to keep their land as long as it is in production. This gives priority to production over conservation use (or lack of using the land), thus incentivizing agricultural production and the opening up of new lands. Thus, the history of Brazil is characterized by a steady movement of people into frontier areas, first from Northeast Brazil to the Southeast and South, and then to the Central plateau and the North Region of the Amazon. This expansion is sustained by the deforestation of new areas, which are then put into agro-pastoral production. Since the use of cattle is the best way to prove that land is being used to fulfill its social function, using them to occupy vast areas allows a relatively small population to occupy large areas and ensure property rights. Over time, some of those lands may be converted to cropped areas when infrastructure and economic opportunities arise. To this day, the cattle ranching sector is the most responsible for deforestation, and occupies the largest portion of land in the agricultural sector.

There is considerable land concentration in Brazil, which dates back to the occupation of the Northeast in the 17th century. Plantations and cattle ranches dominate the landscape, with "latifundio" owners in possession of most of the land, and most rural people being landless. There has never been a major land reform in Brazil. Land "redistribution" has largely been done by expanding the occupation of land from the coastline toward the vast interior. In the 1940s, efforts were made to define a "March to the West" to encourage the country to move to the opportunities that the frontier opened up. The move of the capital from Rio de Janeiro to Brasilia in the 1950s was but one of many steps taken to move the country's attention to the vast areas of unoccupied land in Central Brazil [19]. Since Brasilia is located in the Cerrado biome, this highlighted to citizens the opportunities that beckoned in this thinly populated part of the country. Prior to the 1970s, the Cerrado biome (tropical savanna) was occupied by cattle ranches using natural grasslands. Later, it was the site of an extensive and mechanized system of food commodity production, when agronomic solutions to putting these lands into cultivation became available. This also happened to coincide with China's need for soybean imports in the mid-1980s [20]. The other part of the vast interior of the country is the tropical moist forests of Amazonia. It too became an object of occupation for the agrarian economy—-following a similar trajectory led by cattle ranching—which received significant incentives at the start of the 1970s and thereafter [21,22]. 
Development programs encouraged investment in land to occupy these vast interior regions. In the 1970s, the Federal Government launched several development programs. Among them was the POLOCENTRO (Program of Cerrado Development), to stimulate the development of the Central-West region of Brazil, and to diminish the socioeconomic gap between this region and Southern Brazil. Throughout these development policies, farm credit was abundant to stimulate the expansion of the large-scale farm operations in the Cerrado biome. The farm credit via POLOCENTRO was destined to boost the acquisition of land and large-scale farming [23]. Road-building programs moved settlers to these new areas (e.g., the Trans-Amazonian Highway), and provided them with housing and startup funds $[24,25]$. Larger scale investments in expanding land occupation that favored soybeans began in the 1970s, to move the entrepreneurial gauchos from Rio Grande do Sul and Santa Catarina first towards Paraná, and then to Goiás, Mato Grosso, and further North. In the 1980s, the Center of Agricultural Research of the Cerrado of Embrapa (Brazilian Agricultural Research Corporation), achieved a technological breakthrough that made it possible to make the soils of the Cerrado biome capable of producing soybeans. The Cerrado biome was previously limited by the dry season wilting of soybeans because of shallow root penetration due to high aluminum saturation in the typical Oxisol soils. Correcting this limiting factor suddenly permitted deep root penetration, and thus prevented crop wilting. The tendency of property rights in Brazil to favor the large-scale occupation of new lands, the technical breakthrough that made vast areas of the flat terrain of the central plateau available to plant soybeans, and the demand from China for soybeans led highly capitalized farmers into the region, and gave impulse to the expansion of soybean production. Not all those who came were highly capitalized, but they were able to sell their valuable lands in Southern Brazil and purchase much larger acreage in what were inexpensive areas of Cerrado.

Credit policy has favored large owners and export crops in the agricultural sector [23]. Unlike China, which has a very dense population of mostly rural people, Brazil has been mostly urban for most of the 20th century, and is currently $90 \%$ urban. The rural land areas have largely been owned by a relatively small number of owners. One important factor in this process has been land tenure. The land titling situation in Brazil has always been a bit unclear, especially in frontier areas, but these new settlers were generally savvy and experienced with land titling. They quickly registered their land legally, upending a very old tradition of use rights that were informally held but never legalized at land recorders' offices. The soybean growers quickly capitalized their farms, employed largely seasonal laborers, and used sophisticated mechanization. This was unlike other sectors of agriculture which remain to this day "traditional" (meaning low investment, extensive rather than intensive, and taking advantage of low rural wages rather than taking advantage of technological inputs). This was a new kind of agriculture for Brazil, which banks and credit agencies encouraged as part of a plan to gain worldwide recognition as a leading commodity exporter.

The epicenter of soybean production is Mato Grosso state. According to the Director of the Mato Grosso Institute of Agricultural Economics (IMEA) [26], 50\% of soybean producers have less than 1000 hectares, 33\% have from one thousand to three thousand hectares, $13 \%$ have from three to ten thousand hectares, and 5\% have more than 10,000 hectares in their farm units. Some producers, such as the Amaggi Group, manage exceptionally large extensions of land. According to a 2016 report, the Amaggi Group planted 282 thousand hectares in total (155,550 hectares of soybean; 8063 hectares for soybean seed production; 66,245 hectares of maize, and 52,460 hectares of cotton) [27]. The Amaggi Group controls and manages the Northeast Export Corridor via the ports of Porto Velho in Rondonia and Itacoatira in Amazonas state. From there, the commodities go to Europe and Asia. In newer areas being developed, such as MATOPIBA (Maranhão, Tocantins, Piauí, and Bahia), the average farm size is considerably smaller, but likely to scale up in size as they reach the current day-maturity of Mato Grosso (a maturation which took some 25 years). 


\section{China's Transformation}

Within the telecoupled system created by the soybean trade, China has an interesting role regarding its natural resources. In China, the forestry sector aims to preserve the area and quality of forests to ensure the sustainable development of the country [13]. This objective is accompanied by the forestry industries' desire to grow, and the need to improve land tenure security, which as explained above was addressed by the RLCL. Nonetheless, tenure insecurity remains a major issue [13,15]. Li [14] emphasized that there is a prevalence of informal practices in China that permit the continuation of land transfers, through short-term or at will contracts, which turn out to be uncompensated. Furthermore, the author finds this to be the result of farmers not knowing how to dispute these cases. The author finds also that there is a lack of a land registration system, despite the RLCL's requirement for the registration of rural lands. There is still a disconnect between the de-facto and de-jure rules, particularly in the most remote areas.

The importation of soybeans to China has made it easier to regenerate some of the natural systems it had previously degraded, particularly areas prone to erosion. According to Fao [28], there was a net gain of more than 2.2 million hectares in Asia's forested area between 2000 and 2010. According to this report, the net gains are largely the result of China's afforestation initiatives [28]. China is paying particular attention to efforts to regenerate forests as carbon sinks, as well as strategies for the protection of water and to reduce erosion [29].

By importing the needed soybeans to increase meat production, China has been able to expand the area that it can dedicate to other uses besides soybean production. Any additional soybean production would have required more land to be put into production. Instead, it can import soybeans at a lower cost than could be produced in China, and permit other land uses in those areas. By incentivizing forest growth through its Natural Forest Conservation program, and its Grain-to-Green national program, the Chinese government has incentivized the restoration and conservation of forests in environmentally sensitive areas. This process of substituting internal commodity production with imports has occurred time and again across the world. Europe did this a long time ago-e.g., during the age of mercantilism-by having the New World produce basic commodities for its consumption. It is the children of some of these European immigrants to Brazil that are now the leaders of soybean expansion in Brazil. Moreover, Brazil (e.g., with support from Japan) is expanding agriculture-including soybeans-to Africa, as it did previously to Bolivia and Paraguay [21,30,31]. The response of European farmers, and the possible response of the African farmers, does and will depend on the property rights regime that each of their regions has. In the following section, we will explain how each of these programs works within the rural areas of China.

\subsection{Natural Forest Conservation Program}

This program was established in 1998. Its objectives are to restore the natural forests in ecologically sensitive areas; protect soil and water; increase the production of timber in forest plantations; protect natural forests from overexploitation; and permit the sustained multiple use policy [32]. The objectives mentioned above are sought through the implementation of a variety of policy approaches including technical training and education, land management planning, the mandatory conversion of marginal farmlands to forest lands (offering food to farmers affected), the resettlement and retraining of forest dwellers, and sharing in privately owned non-timber products.

This policy resulted in decreased timber harvesting in natural forests, going from 18.5 to 11 million $\mathrm{m}^{3}$ in China and inner Mongolia between 1997 and 2003; there have also been reports of an increase in forested area to almost 11 million hectares by 2005 [33]. In the reforested areas, there is an increased need to diversify the species used, since only one or a few species were used in the effort, which hurts the need to recover biodiversity [33]. 


\subsection{Grain-to-Green Project}

The Grain-to-Green project, also known as The Sloping Land Conversion Program, is a program that seeks to restore areas of ecological significance. It has been in place since 1999. Its objective is to improve "ecological conditions by converting cultivated land with a slope greater than 25 degrees to forest or grassland" [34]. It is an incentive-based program, which offers in kind (food) and cash subsidies (2250 kg of grain/ha and $300 ¥ / \mathrm{ha}$ ) for the conversion of cropland to forest or grassland. This compensation is supposed to cover the basic subsistence needs of the households from cultivating the land for 8 years [34]. This compensation is offered in exchange for ecosystem services (carbon sequestration or water and erosion protection). Through the Grain-to-Green program, China had converted almost 9 million ha of cultivated land into forest or grasslands by 2006 [35].

Under Schlager and Ostrom's [12] property rights typology, Chinese farmers hold rights of access, withdrawal, management, and exclusion. Farmers have the right to transfer land, and contracting and operation rights, which would be considered rights of alienation. However, since the state is the owner of the land and farmers hold leases over their rights, the rights may be taken away at any point in time, diminishing their alienation rights. It is based on land tenure security that individuals will have (or not have) an incentive to seek sustainable practices and invest in projects such as replanting a forest. Through these two programs, the government provides incentives for farmers to align their management rights with those of the government. In the first case, it provides alternative income sources by retraining farmers for off-farm jobs and providing resettlement options. The second case is a payment for an ecosystem services scheme, where the government becomes the buyer of the services and the producer sells ecosystem services (carbon sequestration or water and erosion protection) [36]. This role of the government in directing property rights in China has been instrumental in the way its food needs are met. It is not at all obvious that in a Brazilian property rights context the same thing would have happened. In a hypothetical case where Brazil had to meet an increased demand for animal protein in its domestic market, it would most likely expand the area in pasture for cattle; or, less likely, expand land area in soybeans to meet that demand. The increased demand would have been met internally because it has a property rights system that favors land expansion with large private property rights. Because it still has $80 \%$ of the Amazon rainforest standing, it stands in a favorable position in the global community with regards to carbon stocks. Brazil also lacks the foreign exchange and favorable trade position that the Chinese economy has enjoyed for several decades. China, in contrast, has small properties, relatively stable ownership under ultimately governmental control, and it favors centralized decision processes to how to respond to a surge in internal demand. China's decision to import the additional soybean demand for production of animal protein took into account internal land property rights, the desire to sequester more carbon to meet international agreements, and a way to continue to urbanize its rural population.

\section{Brazil's Transformation}

The telecoupling of Brazil's human and natural systems with the Chinese ones has increased pressure on its natural ecosystems. This pressure, initially diffused by the Forest Code that strongly protects the Legal Amazon, has created unintended pressures in the Cerrado. The Legal Amazon (5,020,000 $\mathrm{km}^{2}$ of extension), created in 1953, corresponds to the area of the Brazilian states located in the North Region (Acre, Amapá, Amazonas, Pará, Rondônia, Roraima and Tocantins), plus the totality of the State of Mato Grosso, and the municipalities of the Maranhão State located west of the meridian $44^{\circ} \mathrm{W}$. The Cerrado has received the greatest pressure from soybean land expansion, in part due to the restriction of the laws protecting the Legal Amazon (e.g., each landowner in the Amazon is supposed to keep $80 \%$ of the property as a legal reserve, as compared with $30 \%$ in the Cerrado). To protect the sustainability of its ecosystems, Brazilian law uses a land sparing initiative through the Brazilian Forest Code, which imposes a legal reserve of natural ecosystems the size of which depends on the ecosystem where the property is present. In the next section of the paper, we describe the Forest Code in the Brazilian context as it relates to the protection of Brazil's natural systems. 


\section{The Brazilian Forest Code}

Since 1934, Brazil has had a Forest Code subordinating private property to the collective interest of society, and which established a responsibility for land holders to conserve forests [37]. The military government that took over in 1964 prioritized the integration of the Amazon region into the national economy through colonization and agricultural expansion [25,38]. According to Banerjee et al. [38], by the 1960s the Brazilian Atlantic Forest was heavily deforested and fragmented, while the Amazon remained intact until the early 1970s. Until then, the legal instruments put in place to control deforestation-including another forest code issued to protect Brazil's great natural wealth (the 1965 Forest Code) - were ineffective to protect the Atlantic Forests. The isolation of the Amazon provided protection more than the law itself; however, after roads began to be built in the 1970s, this protection began to erode, and deforestation took off in the Amazon region since the model for economic growth in the nation was driven by resource extraction [38]. Furthermore, the recent reforms in the Forest Code can be perceived as an amnesty for farmers who deforested illegally during recent decades [39].

Enforcement has always been a challenge in Brazil. Policies such as the Forest Code provide a legal framework in which to protect national ecosystems, but the lack of enforcement creates a sense of impunity when the code is violated (e.g., illegal deforestation), which has been a common practice until recently. Exceptions occur in some states, such as São Paulo, where there has been significant resource depletion, and where, in turn, civil society has moved to protect what remains. Bicudo da Silva et al. [19] found that São Paulo citizens actively protect the forests—even young secondary forests—and a forestry police effectively enforces what are seen to be environmental crimes $[19,40]$.

The Forest Code of 1965 determined the legal reserve, which required all private properties to 'reserve' (put aside) a percentage of their forested land: 50\% in the Legal Amazon and 20\% in other regions [37]. In 1996, as a response to the high levels of deforestation seen in 1995, the legal reserve adopted a temporary measure, which increased the legal reserve on rural properties from $50 \%$ to $80 \%$ (in the Amazon), as well as prohibiting all new clearings on properties with already abandoned or unused areas. This measure became law in 2001 in spite of opposition from the agribusiness lobby, which was met by the environmental lobbies [37,38]. Finally, in 2012, a new forest code was introduced, which established a minimum property size to institute a legal reserve, and allowed the legal reserve to be settled outside the rural property but still inside the biome where the rural property lies. This created an opportunity for farmers to keep their productive lands in use and purchase other lands inside the legal boundaries of the biome to establish their legal reserves.

Between 2002 and 2008, the average annual rate of deforestation in the Cerrado was twice as high as in the Amazon [41]. This was due to the improved enforcement of illegal deforestation penalties, and monitoring in the Amazon that brought down rates significantly after 2004. During 2001-2004, Morton et al. [41] found that soybean production was an important driver of deforestation in the Amazon portion of the Mato Grosso state, which had contributed with around $17 \%$ of deforestation rates. During 2006 and 2007, Macedo et al. [42] found this pattern was interrupted and soybean production decreased, while the next two years saw a recovery in production due to increased yields and planted area. During the end of the decade, most of the expansion occurred in previously cleared lands. This up and down cycle of deforestation has to do with ambiguities in the application of the law, and the difficulty of enforcing the legal reserves in distant areas such as the Amazon.

Soybean expansion has greatly affected the Amazon, through the replacement of pasturelands with grain production [43,44]. Morton et al. [43] found a strong correlation between high soybean prices and deforestation in the Amazon, which refutes the claim that soybean production is not increasing the pressure on this biome. In response to this, major international soybean traders agreed to sign the Soybean Moratorium, which banned the purchase of grain grown on lands that were deforested after July 2006. This moratorium was extended to May 2016, by which time it was expected that the Brazilian government would have robust legislation, and the capacity to enforce the new Forest Code in such a way that a moratorium would be needless [44]. The jury is out on whether this has in fact occurred. 
Currently, "[m]ore than 20 Mha of natural vegetation in the Cerrado are considered suitable for soybean expansion, and up to 11 Mha of these lands could be legally converted under the Forest Code." [44]. These findings have stressed the need to improve the current Forest Code to become more restrictive, in order to protect the Brazilian biomes that may potentially be affected by the soybean expansion. Unfortunately, there is evidence of an uptick in deforestation in the legal Amazon in 2016 when compared with 2015, according to the Brazilian National Institute of Space research (INPE) (Figure 3). This is probably a result of the economic recession, and a lack of funds for law enforcement.

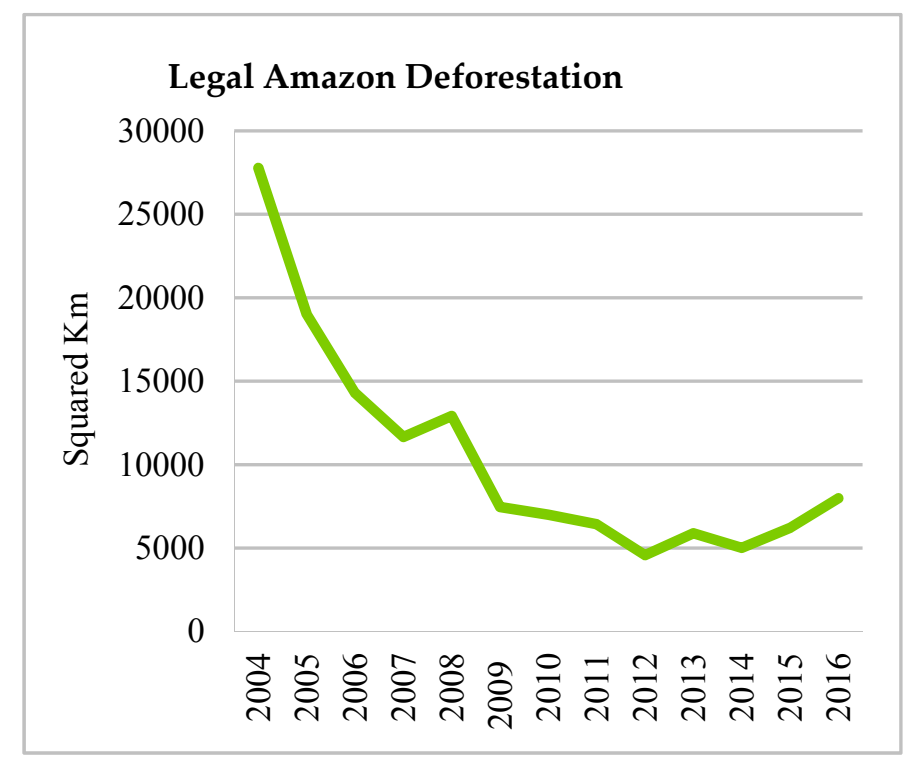

Figure 3. Legal Amazon deforestation (data source INPE [45]).

\section{Discussion and Conclusions}

Through exploring the strategies of Brazil to protect its biodiversity (e.g., protecting natural vegetation areas by the Forest Code), and those of China-allowed in part by the externalization of soybean production - to restore and conserve forests and ecologically sensitive areas, it is important to discuss the ways in which these initiatives may be shaped by the bundles of rights offered in each country.

Both countries are exerting their power to boost their environmental sustainability. China uses an incentive-based strategy that seeks to manipulate the management rights of farmers and their preferences. Brazil uses legislation to define the allowed withdrawal rights through the requirement of sustainable use and a robust if not always enforced legislation over mandated protected areas within properties.

The requirement of a legal reserve in Brazil, with special rules for the legally defined Amazon, has created unintended consequences on other biomes, resulting in the displacement of deforestation to areas with smaller required conservation areas. These newly encountered situations are reflective of the way Brazil has protected its natural wealth, i.e., by choosing the most known and valued ecosystem (in biodiversity and carbon terms). In doing so, it has created great pressure on the Cerrado biome, which is an important biodiversity hotspot. Studies of biodiversity and conservation in the Cerrado provide evidence for its high biodiversity in plant, bird, insect, reptile, and amphibian species. They highlight the disproportionate efforts of preservation compared to ones observed in the Amazon [46-48]. By devaluing or not fully valuing the Cerrado, the doors are open to agribusiness to develop, unimpeded by considerations of ecological value.

In the case of China, the implementation of the Natural Forest Conservation and Grain-to-Green programs has overlooked the need to enforce the use of diverse species in the restoration of natural 
ecosystems, rather than the adoption of single species with economic value in a monoculture forest plantation system (with preference for pine, eucalyptus, or bamboo, depending on the ecological zone). Overlooking such diversity for the restoration of its natural ecosystems is reflective of the fact that China is responding to two conflicting objectives. One objective is to improve environmental quality. The other is to reforest areas to reduce soil erosion to avoid the damage of floods such as those of 1998. An unintended but beneficial outcome of these reforestation policies has been to increase China's carbon sequestration, and to make it a leader in the climate change community. Single species plantations certainly make it easier to exploit them economically, to locate relevant industrial users within close proximity, and to sequester significant amounts of carbon because of their fast rates of growth.

The international soybean trade has created opportunities in the receiving system-China-that have allowed it to regenerate its lost natural systems (e.g., forest cover areas), or areas prone to erosion and flooding downstream. This allows China to assure itself of timber sources, as well as to improve its international standing in the international climate accords. It has also not forgotten to protect biodiversity, as its continued protection of panda habitats makes clear [49]. It has also created pressures in the sending system-Brazil-that have led to losses of natural ecosystems, particularly in the Cerrado and its ecotones with the Amazon's tropical moist forest biome. These transformations were made all the easier by a system of property rights that favor the expansion of land occupied, in a vast and demographically thinly populated country. Whether from external or internal demand, Brazil has been on a steady path of opening up its vast interior, and favoring very large private properties in doing so. This made it an ideal candidate to respond to China's demand for soybeans, made all the more feasible by technical breakthroughs that made the vast flat Cerrado biome capable of large-scale soybean production, and the timing of China's demand. Brazil has not tried to control the expansion of soybean production; but, rather, to encourage its expansion while making efforts to use legislation to limit deforestation in both the Cerrado and the Amazon, with uneven success due to poor law enforcement.

Through trade, Brazil and China have entered a conversation that will continue to transform each nation's land use despite the great distances separating them. The telecoupling framework allows one to observe how international goals such as carbon sequestration, sustainable development, improved diets, and other goals are being met, or not, at a global scale. It has resulted in very different conclusions than those that could have been reached using more traditional, single-country analyses. Many current policy frameworks rely on separate analyses of a country's performance with regards to biodiversity, sustainable development goals, or protection of conservation areas. These single-country approaches tend to hide the complex, reciprocal, and systemic nature of how the globalized economy operates. As we have shown in this paper, China and Brazil are tightly telecoupled, each depending on the other as they try to balance environmental and economic objectives. In this accommodation, property rights play an important role. Brazil's history of land use expansion bolstered by property rights that favor large-scale appropriation of new areas suggests that it will continue to be a favorable provider of soybeans (and meat and other commodities). As Brazil improves its enforcement of the Forestry Code, and can protect the legal reserves mandated by law, it will be increasingly able to meet the environmental targets of the international climate change community, and thus achieve what they see as sustainable development goals.

Acknowledgments: This research has been funded by the Complex Dynamics of Telecoupled Human and Natural Systems project (NSF Award number: 1518518) and the Belmont Forum Collaborative Research: Food Security and Land Use: The Telecoupling Challenge (NSF award number \#1531086; we also thank FAPESP award number \#2014/50628-9 and \#2015/25892-7 for support of this work). We thank Prof. Jianguo "Jack" Liu for his comments and contributions to the paper; and to the two anonymous reviewers of the journal who made excellent suggestions.

Author Contributions: All authors contributed extensively to the various phases of the work presented in this paper. 
Conflicts of Interest: The authors declare no conflict of interest. The founding sponsors had no role in the design of the study; in the collection, analyses, or interpretation of data; in the writing of the manuscript, and in the decision to publish the results.

\section{References}

1. The World Bank. The World Bank World Development Indicators. Available online: http://data.worldbank. org/data-catalog/GDP-ranking-table (accessed on 31 January 2017).

2. Larsen, J. Meat Consumption in China Now Double that in the United States. Available online: http://www.earth-policy.org/plan_b_updates/2012/update102 (accessed on 1 December 2016).

3. Liu, H.; Parton, K.A.; Zhou, Z.Y.; Cox, R. At-home meat consumption in China: An empirical study. Aust. J. Agric. Resour. Econ. 2009, 53, 485-501. [CrossRef]

4. The World Bank. The United Nations Population Divisions World Urbanization Prospects. Available online: http:/ / data.worldbank.org/indicator/SP.URB.TOTL.IN.ZS?locations=CN (accessed on 21 May 2017).

5. Weinraub, M. U.S. Agriculture Bets the Farm on Chinese Soy Demand. Available online: http://www.cnbc. com/2017/04/06/reuters-america-us-agriculture-bets-the-farm-on-chinese-soy-demand.html (accessed on 21 May 2017).

6. Ministério da Agricultura Pecuária e Abastecimento. AGROSTAT. Available online: http://sistemasweb. agricultura.gov.br/pages/AGROSTAT.html (accessed on 21 May 2017).

7. Liu, J.; Hull, V.; Batistella, M.; DeFries, R.; Dietz, T.; Fu, F.; Hertel, T.W.; Izaurralde, R.C.; Lambin, E.F.; Li, S.; et al. Framing Sustainability in a Telecoupled World. Ecol. Soc. 2013, 18, 26. [CrossRef]

8. Spera, S.A.; Galford, G.L.; Coe, M.T.; Macedo, M.N.; Mustard, J.F. Land-use change affects water recycling in Brazil's last agricultural frontier. Glob. Chang. Biol. 2016, 22, 3405-3413. [CrossRef] [PubMed]

9. Instituto Brasileiro de Geografia e Estatística. Municipal Agricultural Production: Systematic Rural Census Addressed to Rural Properties in the Brazilian Countryside Every Year Since 1990. Available online: https://sidra.ibge.gov.br/pesquisa/pam/tabelas (accessed on 2 May 2017).

10. Keenan, R.J.; Reams, G.A.; Achard, F.; de Freitas, J.V.; Grainger, A.; Lindquist, E. Dynamics of global forest area: Results from the FAO Global Forest Resources Assessment 2015. For. Ecol. Manag. 2015, 352, 9-20. [CrossRef]

11. Bromley, D.W. Environment and Economy: Property Rights and Public Policy; Basil Blackwell: New York, NY, USA, 1991.

12. Schlager, E.; Ostrom, E. Property-Rights regimes and natural resources: A conceptual analysis. Land Econ. 1992, 68, 249. [CrossRef]

13. Kram, M.; Bedford, C.; Durnin, M.; Luo, Y.; Rokpelnis, K.; Roth, B.; Smith, N.; Wang, Y.; Yu, G.; Yu, Q.; et al. Land Tenure. In Protecting China's Biodiversity: A Guide to Land Use, Land Tenure E Land Protection Tools; Smith, N., Ed.; The Nature Conservancy: Beijing, China, 2012; pp. 61-126.

14. Lin, J.Y. The household responsibility system reform in China: A peasant's institutional choice. Am. J. Agric. Econ. 1987, 69, 410. [CrossRef]

15. Li, P. Rural land tenure reforms in China: Issues, regulations and prospects for additional reform. Land Reform Land Settl. Coop. 2003, 11, 59-72.

16. Deininger, K.W. Land Policies for Growth and Poverty Reduction; The World Bank and Oxford University Press: Oxford, UK; New York, NY, USA, 2003.

17. Vergara-Camus, L. The legacy of social conflicts over property rights in rural Brazil and Mexico: Current land struggles in historical perspective. J. Peasant Stud. 2012, 39, 1133-1158. [CrossRef]

18. Ondetti, G. The social function of property, land rights and social welfare in Brazil. Land Use Policy 2016, 50, 29-37. [CrossRef]

19. Da Silva, R.F.B.; Batistella, M.; Moran, E.F.; Lu, D. Land changes fostering Atlantic forest transition in Brazil: Evidence from the Paraíba Valley. Prof. Geogr. 2017, 69, 80-93. [CrossRef]

20. Sano, E.E.; Rosa, R.; Brito, J.L.S.; Ferreira, L.G. Land cover mapping of the tropical savanna region in Brazil. Environ. Monit. Assess. 2010, 166, 113-124. [CrossRef] [PubMed]

21. Arvor, D.; Tritsch, I.; Barcellos, C.; Jegou, N.; Dubreuil, V. Land use sustainability on the South-Eastern Amazon agricultural frontier: Recent progress and the challenges ahead. Appl. Geogr. 2017, 80, 86-97. 
22. Nepstad, D.; McGrath, D.; Stickler, C.; Alencar, A.; Azevedo, A.; Swette, B.; Bezerra, T.; DiGiano, M.; Shimada, J.; da Motta, R.S.; et al. Slowing Amazon deforestation through public policy and interventions in beef and soy supply chains. Science 2014, 344, 1118-1123. [CrossRef] [PubMed]

23. Vieira, N. de M. Caracterização da Cadeia Produtiva da Soja em Goiás; Universidade Federal de Santa Catarina: Florianópolis, Brazil, 2002.

24. Moran, E.F. Roads and dams: Infrastructure-driven transformations in the Brazilian amazon. Ambient. Soc. 2016, 19, 207-220. [CrossRef]

25. Moran, E.F. Developing the Amazon; Indiana University Press: Bloomington, IN, USA, 1981.

26. Latorraca Ferreira, D. O Perfil do Produtor Matogrossense. Available online: http://www.aprosoja.com.br/ comunicacao/apresentacao/o-perfil-do-produtor-mato-grossense (accessed on 15 May 2017).

27. Amaggi. Numeros Amaggi Agro. Available online: http://amaggi.com.br/divisao-agro/apresentacao/ numeros-da-divisao-agro/ (accessed on 3 June 2017).

28. FAO. Global Forest Resource Assessment. 2010. Available online: http://www.fao.org/docrep/013/i1757e/ i1757e.pdf (accessed on 15 December 2017).

29. Viña, A.; McConnell, W.J.; Yang, H.; Xu, Z.; Liu, J. Effects of conservation policy on China's forest recovery. Sci. Adv. 2016. [CrossRef]

30. Clements, E.A.; Fernandes, B.M. Land grabbing, agribusiness and the peasantry in Brazil and Mozambique. Agrar. South J. Political Econ. 2013, 2, 41-69. [CrossRef]

31. Gasparri, N.I.; Waroux, Y.L.P. The coupling of South American soybean and cattle production frontiers: New challenges for conservation policy and land change science. Conserv. Lett. 2015, 8, 290-298. [CrossRef]

32. Zhang, P.; Shao, G.; Zhao, G.; Le Master, D.C.; Parker, G.R.; Dunning, J.B.; Li, Q. China's forest policy for the 21st century. Science 2000, 288, 2135-2136. [CrossRef] [PubMed]

33. Liu, J.; Li, S.; Ouyang, Z.; Tam, C.; Chen, X. Ecological and socioeconomic effects of China's policies for ecosystem services. Proc. Natl. Acad. Sci. USA 2008, 105, 9477-9482. [CrossRef] [PubMed]

34. Xu, J.-Y.; Chen, L.-D.; Lu, Y.-H.; Fu, B.-J. Sustainability evaluation of the Grain for Green Project: From local people's responses to ecological effectiveness in Wolong Nature Reserve. Environ. Manag. 2007, 40, 113-122. [CrossRef] [PubMed]

35. Qu, F.; Kuyvenhoven, A.; Shi, X.; Heerink, N. Sustainable natural resource use in rural China: Recent trends and policies. China Econ. Rev. 2011, 22, 444-460. [CrossRef]

36. Ouyang, Z.; Zheng, H.; Xiao, Y.; Polasky, S.; Liu, J.; Xu, W.; Wang, Q.; Zhang, L.; Xiao, Y.; Rao, E.; et al. Improvements in ecosystem services from investments in natural capital. Science 2016, 352, 1455-1459. [CrossRef] [PubMed]

37. Stickler, C.M.; Nepstad, D.C.; Azevedo, A.A.; McGrath, D.G. Defending public interests in private lands: Compliance, costs and potential environmental consequences of the Brazilian Forest Code in Mato Grosso. Philos. Trans. R. Soc. Lond. B. Biol. Sci. 2013, 368, 20120160. [CrossRef] [PubMed]

38. Banerjee, O.; Macpherson, A.J.; Alavalapati, J. Toward a policy of sustainable forest management in Brazil: A historical analysis. J. Environ. Dev. 2009, 18, 130-153. [CrossRef]

39. Soares-Filho, B.; Rajão, R.; Macedo, M.; Carneiro, A.; Costa, W.; Coe, M.; Rodrigues, H.; Alencar, A. Cracking Brazil's forest code. Science 2014, 344, 363-364. [CrossRef] [PubMed]

40. Da Silva, R.F.B.; Batistella, M.; Moran, E.F. Drivers of land change: Human-environment interactions and the Atlantic forest transition in the Paraíba Valley, Brazil. Land Use Policy 2016, 58, 133-144. [CrossRef]

41. Instituto Brasileiro de Geografia e Estatística. Indicadores de Desenvolvimento Sustentavel. Brasil 2010/IBGE; Coordenação de Recursos Naturais e Estudos Ambientais, Coordenação de Geografia IBGE: Rio de Janeiro, Brazil, 2010.

42. Macedo, M.N.; DeFries, R.S.; Morton, D.C.; Stickler, C.M.; Galford, G.L.; Shimabukuro, Y.E. Decoupling of deforestation and soy production in the southern Amazon during the late 2000s. Proc. Natl. Acad. Sci. USA 2012, 109, 1341-1346. [CrossRef] [PubMed]

43. Morton, D.C.; DeFries, R.S.; Shimabukuro, Y.E.; Anderson, L.O.; Arai, E.; del Bon Espirito-Santo, F.; Freitas, R.; Morisette, J. Cropland expansion changes deforestation dynamics in the southern Brazilian Amazon. Proc. Natl. Acad. Sci. USA 2006, 103, 14637-14641. [CrossRef] [PubMed]

44. Gibbs, H.K.; Rausch, L.; Munger, J.; Schelly, I.; Morton, D.C.; Noojipady, P.; Soares-Filho, B.; Barreto, P.; Micol, L.; Walker, N.F. Brazil's soy moratorium. Science 2015, 347, 377-378. [CrossRef] [PubMed] 
45. Projeto Prodes. Monitoramento da Floresta Amazônica Brasileira Por Satélite. Available online: http:/ / www.obt.inpe.br/prodes/index.php (accessed on 3 June 2017).

46. Klink, C.A.; Machado, R.B. Conservation of the Brazilian Cerrado. Conserv. Biol. 2005, 19, 707-713. [CrossRef]

47. Bridgewater, S.; Ratter, J.A.; Felipe Ribeiro, J. Biogeographic patterns, -diversity and dominance in the cerrado biome of Brazil. Biodivers. Conserv. 2004, 13, 2295-2317. [CrossRef]

48. Ratter, J.; Ribeiro, J.F.; Bridgewater, S. The Brazilian Cerrado vegetation and threats to its biodiversity. Ann. Bot. 1997, 80, 223-230. [CrossRef]

49. Liu, J.; Hull, V.; Yang, W.; Viña, A; Chen, X.; Ouyand, Z.; Zhang, H. Pandas and People: Coupling Human and Natural Systems for Sustainability, 1st ed.; Oxford University Press: Oxford, UK, 2016.

(C) 2017 by the authors. Licensee MDPI, Basel, Switzerland. This article is an open access article distributed under the terms and conditions of the Creative Commons Attribution (CC BY) license (http://creativecommons.org/licenses/by/4.0/). 